Research

\title{
Drivers of sustainability practices and contributions to sustainable development evident in sustainability reports of European mining companies
}

\author{
Anđela Ivic ${ }^{1}$ - Nína María Saviolidis ${ }^{1} \cdot$ Lara Johannsdottir $^{1}$
}

Received: 4 February 2021 / Accepted: 5 March 2021

(c) The Author(s) 2021 OPEN

\begin{abstract}
Mining activities cause negative environmental impacts and social conflicts but also provide economic benefits to communities and secure the minerals necessary for low-carbon technology. The aim of this multiple case study is to analyze, compare and critically evaluate sustainability reports of 10 European mining companies for the 2016-2018 period to determine the drivers for implementation of sustainability practices and their contribution to the Sustainable Development Goals (SDGs). The findings suggest that European mining companies act under pressures from international initiatives and industry associations, the European Union, governments, stakeholders, and maintaining social license to operate. The companies report on the core subjects of corporate governance, employees, the environment, stakeholders' engagement and occupational health and safety. Positive trends were observed in stakeholders' engagement and health and safety, while air emissions and water and energy usage increased for most companies. Furthermore, there was an absence of improvement in gender diversity, utilization of renewable energy, and waste recycling. Even though all analyzed companies mentioned SDGs in the reports, the reports lacked a comprehensive explanation of mining activities' contribution to the SDGs. This study addresses a gap in the existing literature on the European mining context of sustainable development and SDGs relevant for researchers, policymakers, and other impacted stakeholders and adds new theoretical knowledge on the external drivers of CSR activities based on institutional theory.
\end{abstract}

Keywords Mining · Europe · Sustainability reporting · Sustainable Development Goals · Institutional theory

$\begin{array}{ll}\text { Abbreviations } \\ \text { EU } & \text { European Union } \\ \mathrm{NGO} & \text { Non-governmental organization } \\ \text { ICMM } & \text { International Council on Mining and Metals } \\ \mathrm{GRI} & \text { Global Reporting Initiative } \\ \mathrm{SDGs} & \text { Sustainable Development Goals } \\ \mathrm{CSR} & \text { Corporate Social Responsibility } \\ \mathrm{UNGC} & \text { United Nations Global Compact } \\ \mathrm{GHG} & \text { Greenhouse gas emissions } \\ \mathrm{SO}_{2} & \text { Sulphur dioxide } \\ \mathrm{NO}_{\mathrm{x}} & \text { Nitrogen oxides } \\ \mathrm{REACH} & \text { Regulation, evaluation, and authorization of chemicals } \\ \mathrm{EMS} & \text { Environment management systems }\end{array}$

Lara Johannsdottir, lara@hi.is; Anđela Ivic, ani12@hi.is; Nína María Saviolidis, nms@hi.is |'University of Iceland, Reykjavik, Iceland. 
TRIFR Total Recordable Injury Rate

LTIFR Lost-Time Injury Frequency

GDP Gross Domestic Product

\section{Introduction}

Mining ${ }^{1}$ is one of the oldest documented human activities and has advanced the economic, cultural, and technical development of societies and countries throughout human history [1]. In Europe, mining and quarrying the stone has a very long tradition dating to the Neolithic era with extraction sites found in Portugal, Sicily, south of Russia, and north of Norway [2]. The European mining industry is an important part of its economy with an almost self-sufficient production of industrial minerals and aggregates for European requirements [3]; it is a major international producer of many industrial minerals, natural stone with approximately $35 \%$ global production and the largest producer of extracted gypsum in the world [4]. European Union (EU) metal production accounts for only approximately $3 \%$ of the world's production while consuming approximately $30 \%$ of global metal production [5]. However, metal processing, including reuse and recycling, accounts for $46 \%$ of the total manufacturing value in the EU and $11 \%$ of the gross domestic product (GDP) [6].

Mining is considered to conflict with sustainable development due to its use of nonrenewable natural resources and significant impact on the environment [7]. Due to these negative impacts, the mining industry has been under intensified pressure from stakeholders over the last few decades, especially from nonprofit organizations (NGOs), to improve their performance [8]. Moreover, the negative impact has intensified due to the rising demand for materials, increased production, and ore grade decline [9], causing higher waste rock production and greenhouse gas emissions per ton of product [10]. As a result, the mining industry has begun to develop strategies to address concerns about the social and environmental impacts of their operations [8].

The transition to a low-carbon future, based on the Paris Agreement, indicates a potentially increased demand for certain minerals needed for low-carbon technologies, meaning that the extractive industry has an essential role to play towards sustainable development [11, 12]. Furthermore, by providing revenues to countries, driving economic growth, creating jobs, and enabling infrastructural development mining contributes to the economic dimension of sustainable development [13]. The EU's Green Deal, developed in 2019 by the European Commission, is a roadmap for sustainable development executed through resource efficiency, circular economy, biodiversity conservation, carbon neutrality and pollution reduction [14].

The current global primary metal consumption is increasing exponentially [15], which puts further sustainable extraction growth into doubt. To achieve sustainable consumption of primary materials, the current global metal consumption rates need to be considerably reduced from 63\% (copper) to $98 \%$ (antimony) [16]. Recovering metals from secondary materials through the circular economy model could efficiently contribute to increased global demand for raw materials and reduce the dependency on imported materials in Europe [17]. Nevertheless, it should include not only the most valuable metals, such as gold and copper, but also many other metals from industrial residues and consumer waste [12, 18]. Utilizing waste from mining operations and urban mines in Europe, consequently, could improve the limited metal supply, reduce the environmental footprint, and generate profit $[19,20]$. However, as a vital natural resource, mineral extraction, and recycling require global coordination for clear metrics in environmental and economic performance [12]. To adequately address several recycling challenges, harmonized waste legislation, including stronger recycling policies, internationally recognized standards, recovery-efficient product design, and ways to address illegal waste export and trade, is needed $[18,21]$.

The most widespread approach to communicate on the progress toward sustainable development is the issuing of annual sustainability reports through which companies report on the nonfinancial aspects of their business, including environmental and social impacts and corporate governance issues. The Global Reporting Initiative (GRI) Standards are the most commonly used framework in the mining industry, where in $2011,95 \%$ of the 102 global mining companies publishing reports used the GRI [22].

The study aims to examine the sustainability activities of mining companies that operate in Europe by carrying out a content analysis of their sustainability reports. The following research questions were investigated:

\footnotetext{
1 This research excludes petroleum and gas production as it is considered a separate industry.
} 
1. What are the institutional drivers of sustainability practices as detailed in the sustainability reports of European mining companies?

2. What efforts are European mining companies taking to contribute to sustainable development as detailed in their sustainability reports?

3. How well integrated are the SDGs in companies' sustainability reports?

The paper is structured as follows: Sect. 2 discusses the relationship between mining and sustainable development, the challenges of using reported data to analyze performance, and the use of institutional theory as a theoretical lens for the analysis of drivers of sustainability practices. Section 3 introduces the method including the selected criteria for the qualitative content analysis. Section 4 presents the results, while Sect. 5 comprises the discussion. The implications and limitations of the study are addressed in Sect. 6.

\section{Mining and sustainable development}

The conciliation of mining and sustainable development does not imply the end of mining but the rational consumption of limited resources. Sustainable mining includes the implementation of activities in mining operations to reduce negative impacts and addresses stakeholders' interests and concerns [23]. However, producing minerals with less impact is not nearly enough to ensure sustainability, and the use of minerals and metals needs to support ecosystems and human development by broadening the understanding of impacts on a global and local scale (strong sustainability) [24]. Sustainability in mining should include a holistic view of impacts by shifting from the life cycle of the mine to the life cycle of mined minerals, highlighting the importance of recovery, reuse, and responsible sourcing [23, 24]. To promote the environmental dimension of strong sustainability, companies should use resources efficiently, limit the consumption of resources, reduce GHG emissions, implement renewable energy resources and reuse waste [25]. Research from Tost et al. [26] states that none of the analyzed large mining companies support strong sustainability in their reports, especially lacking climate change and natural capital considerations [26]. To address social sustainability, companies must include positive social factors such as good employment opportunities, good working conditions, learning opportunities, gender equality, and diversity of cultural expressions [27, 28].

Mining companies need to identify stakeholders and key sustainability issues and actions to tackle these issues and develop sustainability indicators to measure and monitor performance [29]. Moreover, the improvement in various individual indicators does not necessarily mean overall improvement, and therefore connections, trade-offs and synergies among the impacts should also be considered [30].

While mining results in considerable economic gains [31], the extractive industry is associated with a range of damaging environmental and social impacts (Table 1).

Few studies have explored the sustainability challenges of the mining sector within Europe, as evident in Table 1. Endl et al. [39] explored European mining innovation's contribution to the SDGs, including autonomous equipment and operations, better mine design, enhanced transparency and traceability, renewable energy solutions, and occupational safety. Ranängen and Zobel [38], in a case study of the Swedish mining company Boliden AB, revealed that implementation of international standards does not lead to increased use of renewable energy or result in greenhouse gas emission reductions. Ranängen and Lindman [45] studied the corporate social responsibility (CSR) activities of Nordic mining companies, showing that they mostly complied with stakeholders' interests, such as labor practices, risk management and sustainable water use. However, to gain the crucial social license to operate, anti-corruption, energy and recycling topics could have been covered more thoroughly. Social license to operate comprise the community's intangible consent of the company's operations and extend beyond legal rights [44, 47]. Suopajärvi et al. [46], in a qualitative study of mining operations in the European North and in Northwest Russia, observed that social themes important to local communities are understanding the environmental impact of mining, having a role in mining operation decisions, local benefit from the mine, and consideration of impacts on future generations.

\subsection{Sustainable development goals}

The 17 SDGs, adopted by all UN Member states in 2015, offer a universal framework for navigating the most pressing sustainability challenges of the present and are a call for action to end poverty, protect the planet, and assure peace and prosperity by 2030. All the Goals are interlinked between the economic, social, and environmental dimensions of 
Table 1 Previous research on environmental and social impacts of mining

\begin{tabular}{lll}
\hline Environmental impact & Previous research & Scale of the study \\
\hline Greenhouse gas emissions (GHG) & McLellan et al. [32] & World \\
Air emissions & Asif and Chen [33] & North America \\
Water consumption and pollution & Mudd [34] & World \\
Negative impact on biodiversity & Sonter et al. [35] & World \\
Waste generation & Lottermoser [20] & Chile \\
Significant use of energy & Lèbre et al. [36] & Sweden \\
Renewable energy; GHG emissions & Nasirov and Agostini [37] & Europe \\
SDGs contribution & Ranängen and Zobel [38] & World \\
Climate change, SDGs & Endl et al. [39] & \\
\hline Social impact & Tost et al. [26] & Australia \\
\hline High risk for employees & Previous research & Sweden \\
Attracting and retaining high skill workers & Hebblewhite [40] & Loow and Nygen [41] \\
Low share of female employees & Lahiri-Dutt and Macintyre [42]; Botha [43] & Developing countries; South Africa \\
Health and safety; human and labor rights issues, & Mancini and Sala [44] & World \\
conflicts & Ranängen and Lindman [45] & Nordic countries \\
Social license to operate & Suopajärvi et al. [46] & European North and Northwest Russia \\
\hline
\end{tabular}

Synthesized by the authors

sustainable development, including trade-offs and synergies across the Goals [48]. Interactions in which the progress of one goal supports another one are classified as synergies, while the opposite interaction where one goal's progress hinders another are called trade-offs [49]. Sustainability reporting can influence corporate actions and consequently induce the implementation of the SDGs into business strategy [50] and be a significant driver of an organization's sustainability strategy [51]. However, previous research found that few companies had cited the SDGs in their reports [52, 59]. Additionally, SDG reporting practices have been criticized for "rainbow washing", meaning that companies overuse SDG rainbow wheels focusing on style instead of content [59]. Additionally, some authors emphasized that the reports do not explain how these Goals relate to one another or identify the drivers of the impacts [53, 54]. Integrating SDGs into the core business can lead to cost savings, better alignment with regulations, better relations with communities and stakeholders, and an improved business environment [55].

\subsection{Challenges in using sustainability reports to analyze sustainability performance}

Due to intensified stakeholder pressure in previous decades and mandatory reporting among the members of mineral associations, sustainability reporting has significantly increased among mining companies [56]. The EU directive mandates nonfinancial disclosures by the largest companies, further highlighting that the trend towards more mandatory reporting schemes will continue [57]. In a comparability analysis of $12 \mathrm{GRI}$ reports from mining companies, Boiral and Henri [58] revealed that due to the qualitative characteristics of many GRI indicators, general information, use of different scales, and the lack of data, it was difficult to compare sustainability performance between the reports. Additionally, the contribution to the SDGs included in sustainability reports is often limited with general descriptions but lacks implementation in terms of business models and the development of indicators related to the SDGs [59,60]. However, to reach a higher level of maturity in sustainability reporting, organizations require more time [61].

\subsection{Institutional theory}

Institutional theory takes a broad view in explaining why an organization adopts a particular structure or reporting practice. Companies whose core business is associated with higher environmental impact, such as the mining industry, are under more pressure to act responsibly in the way they conduct their business than companies with lesser environmental 
impact [62]. Institutional theory was used in this study to explain the motivations for engagement in sustainability practices among mining companies through an analysis of their sustainability reports.

Institutional theory clarifies the pressures organizations experience, forcing them to adopt social and institutional norms and rules to increase legitimacy to maintain access to resources, causing organizations within the same organizational field to become more similar to another [63]. The concept describing this process of homogenization is called isomorphism, and according to DiMaggio and Powell [64], it can be categorized as coercive (regulatory), mimetic (competitive), and normative (market) isomorphism.

Coercive isomorphism occurs due to pressure from external factors such as shareholder or employee influence and government policy and legislation/regulations to change an organization's institutional practices [65, 66], e.g., policies or taxes on companies to reduce their businesses' environmental impact. Mimetic isomorphism is the process by which an organization attempts to imitate or copy other organizations' practices, often to gain a competitive advantage regarding legitimacy, such as by implementing CSR reporting $[67,68]$. Normative isomorphism relates to the pressures to adopt institutional practices arising from common values, usually from customers or suppliers that compel them to comply with environmental and social standards [64,68], such as the increased use of the GRI Standards [69] for sustainability disclosure by companies worldwide [70].

In his study of a holistic perspective on corporate sustainability drivers, Lozano [51] classified internal, external, and connecting drivers to engage in CSR. Some of the external drivers were national governments, regulations, legislation, society pressure, stakeholders' expectations, and collaboration with external organizations, while connecting drivers included sustainability reports, license to operate, access to natural resources, and reputation. Building on this research, Latapí Agudelo et al. [71] identified external drivers for the energy sector, including reputation, reporting, and social license to operate as connecting drivers and competitiveness, legislation and regulations, social commitment, and stakeholder engagement as external drivers. Furthermore, Johannsdottir [72] recognized various stakeholders as the most important external driver for large companies, together with legislation and reputation. Industry associations of companies with large negative environmental impacts can also apply pressure on companies through the development of environmental standards or principles [73]. The pressure from media is also increasing, compelling companies to act more responsibly to avoid reputational damage [74].

\section{Sustainability reports' content analysis}

The method employed in this multicase study is based on the content analysis of the sustainability reports from 10 mining companies operating in Europe. A case study is a research method that simplifies the research of trends within its context using a variety of data sources to understand various aspects of a phenomenon [75], including the connections and differences between many cases in a multiple case study [76]. In addition, to gain a broader view of sustainability standards used in the mining industry, a review of the scientific literature and sustainability initiatives was carried out.

\subsection{Data collection}

The main criteria for choosing companies' sustainability reports for the analysis were as follows:

1. Mining companies with a mine or an ore processing plant within Europe.

2. A sustainability framework or standards used for sustainability reports.

3. Sustainability reports publicly published in English.

4. Sustainability reports annually published for the years 2016, 2017, and 2018.

To gather information about mining companies in Europe, the GRI database and a database of the major European mining associations were used [77,78]. Businesses with headquarters in European countries operating only in other parts of the world were not included in the analysis. The final number of companies studied was 10 (see Fig. 1). The literature review was conducted through Science Direct and Google Scholar using keywords such as "mining," "sustainability," report", "SDGs," "CSR," "GRI" and "Europe." Additionally, several papers were found in the reference list of the previously gathered academic papers using the snowball technique, a method of data collection through primary data sources to collect potential additional sources [79]. 


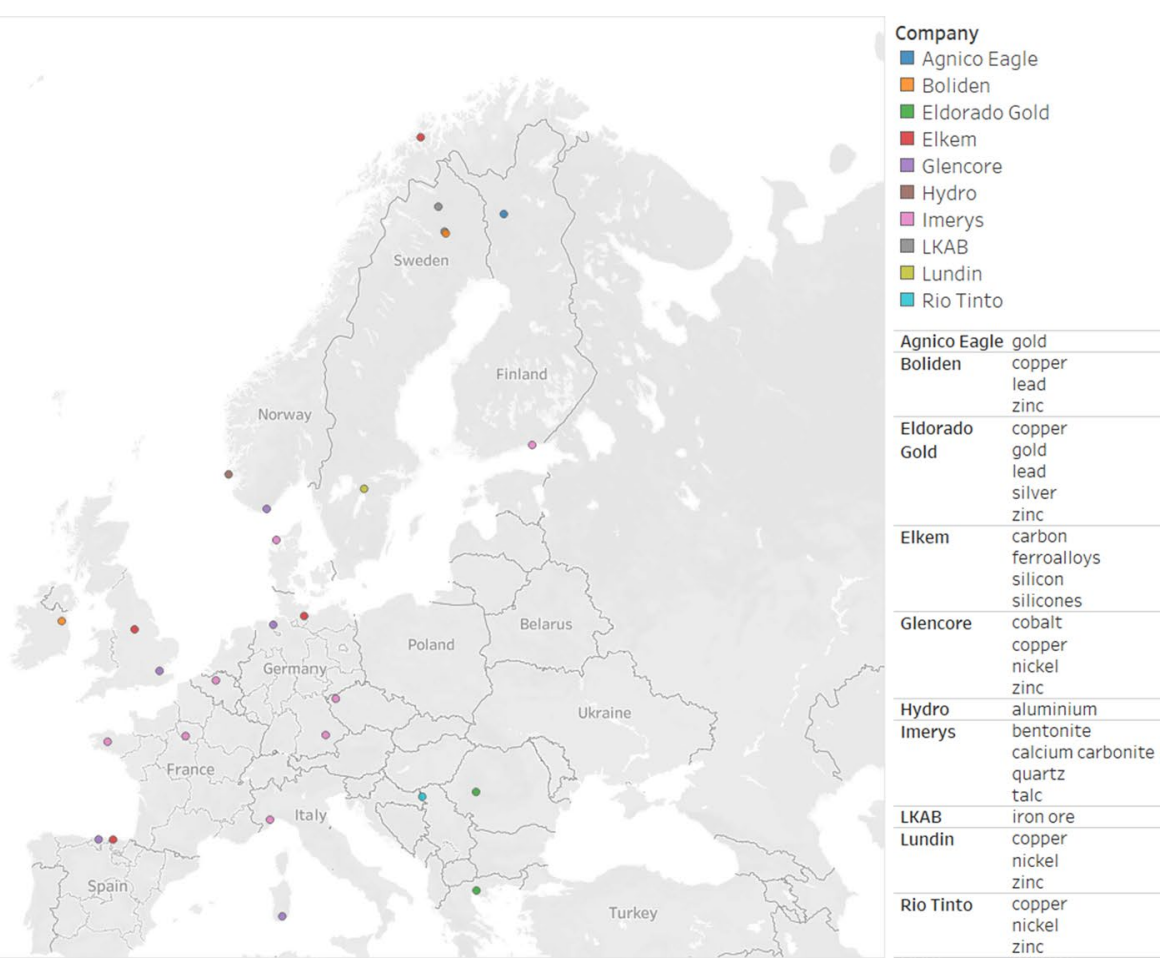

Fig. 1 Map of the analyzed mining companies in Europe and exploited minerals. Synthesized by the authors based on the analysis of the data

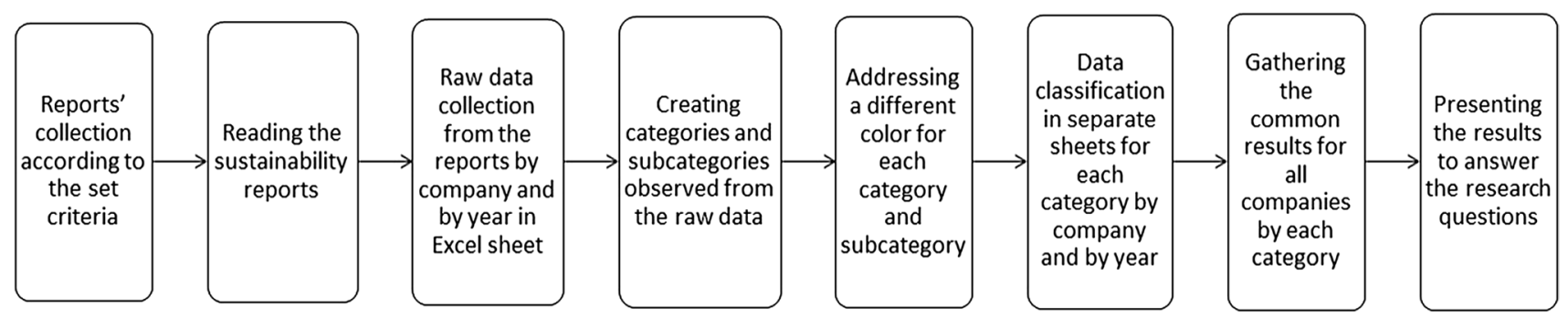

Fig. 2 Content analysis process. Synthesized by the authors

\subsection{Content analysis}

A content analysis of 30 sustainability reports from 10 mining companies published from 2016 to 2018 was carried out, including approximately 2400 pages of text (see Appendix 1). This is a common method applied to define large amounts of quantitative and qualitative data of documents through systematic coding and categorization to group information around concepts or themes [80]. It was performed manually by the first author using an Excel document for collecting data by company and year of publishing of the reports (Fig. 2). The coding process for the content analysis was based on an inductive approach, where the categories are developed from the raw data into a model with key themes [81]. During this process, disclosed materiality topics were observed as a key theme, each marked with a different color, and raw data were sorted in separate sheets according to the key topic (Appendix 2). As certain key themes were related to the broader topic, they were grouped into categories and subcategories, which are presented in the results section. Afterwards, the common data for all studied companies were gathered by each category to answer the research questions.

A qualitative content analysis [80] of the policies, actions, and indicators presented in the sustainability reports was conducted to examine their contribution to the environmental and social dimensions of sustainable development. A quantitative content analysis of the reported indicator data was carried out to determine whether the implemented actions resulted in the improvement or reduction of impacts. In addition, the contribution to the SDGs was determined 
Fig. 3 Trends in the sustainability reporting frameworks used by analyzed companies. Synthesized by the authors based on the analysis of the data

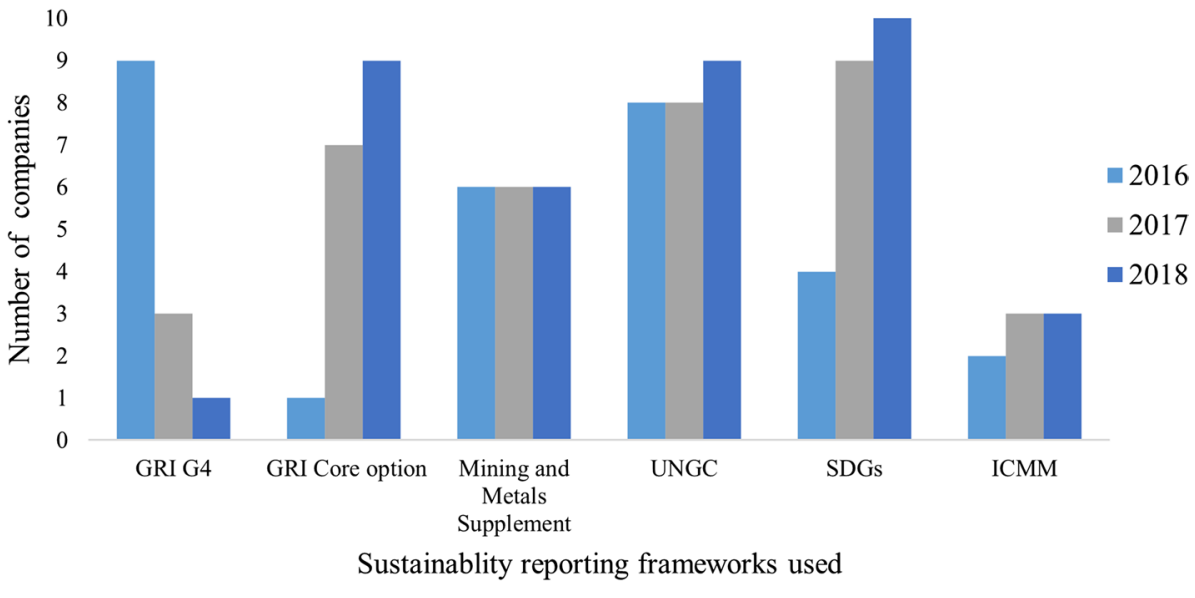

through an examination of whether the SDGs were part of the reports, how the content was linked to the SDGs, and which Goals were the most reported upon. The institutional theory approach was applied to determine under which external pressures mining companies in Europe act, as it provides a basis for explaining why an organization implements a certain structure or reporting practices. The results built upon the most important identified stakeholders and the content from the 2018 reports stating commitment, compliance, relationships with stakeholders, and social acceptance.

\section{Sustainability practices by European mining companies}

The trends in the sustainability frameworks used by analyzed companies over three years are presented in Fig. 3. In the sustainability reports for 2016, almost all the mining companies used the GRI G4 Guidelines: Core option with the majority applying the Mining and Metals Sector Supplement. There was a transition in 2016 due to the change from GRI G4 Guidelines to GRI Standards. Three of the companies as members of the International Council on Mining and Metals (ICMM) are obligated to report using the GRI Standards annually. A notable trend was observed in the use of the UN Global Compact (UNGC) principles, with nine out of 10 UNGC signatories by 2018. Similar improvements were visible in the commitment to the SDGs from only four mining companies in 2016 to the integration of the SDGs into the sustainability strategy and reporting by all companies in 2018.

The findings of the sustainability reports' content analysis are grouped in the resulting topics: governance, stakeholders' engagement, occupational health and safety, and environment, together with the SDGs (Fig. 4.). Each category is divided into the subcategories observed as key themes during the analysis and is discussed in the following sections, together with the results related to SDGs' relation to the core business and institutional drivers of European mining companies. Some categories, such as biodiversity, climate change in a broader view, and product stewardship, were not part of all the studied reports.

\subsection{Corporate governance}

The Code of Conduct was the primary document for the analyzed firms on which the business strategy and ethical behavior of a company were based. Furthermore, companies developed additional policies in terms of health and safety, human rights, anticorruption, environment, and employees. Companies stated that sustainability was an integral part of their business strategy, which was aligned with international standards and commitments such as the UNGC, the SDGs, and the GRI Standards.

\subsection{Stakeholder engagement}

Building a strong relationship and maintaining an open and inclusive dialogue with stakeholders was the main objective for the analyzed companies in terms of their social responsibility. Stakeholders' engagement was recognized as 


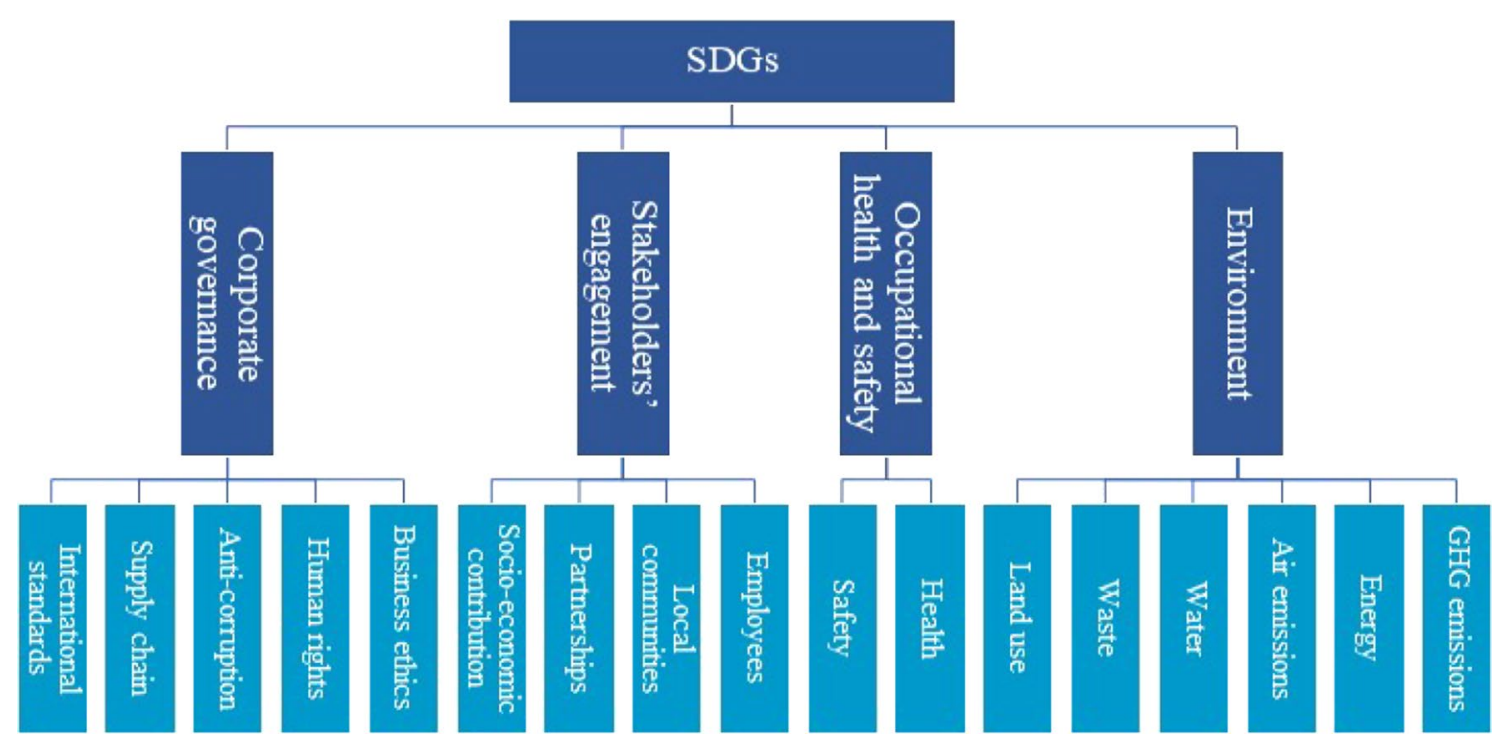

Fig. 4 Categories and subcategories evident from the sustainability reports' content analysis. Synthesized by the authors based on the analysis of the data

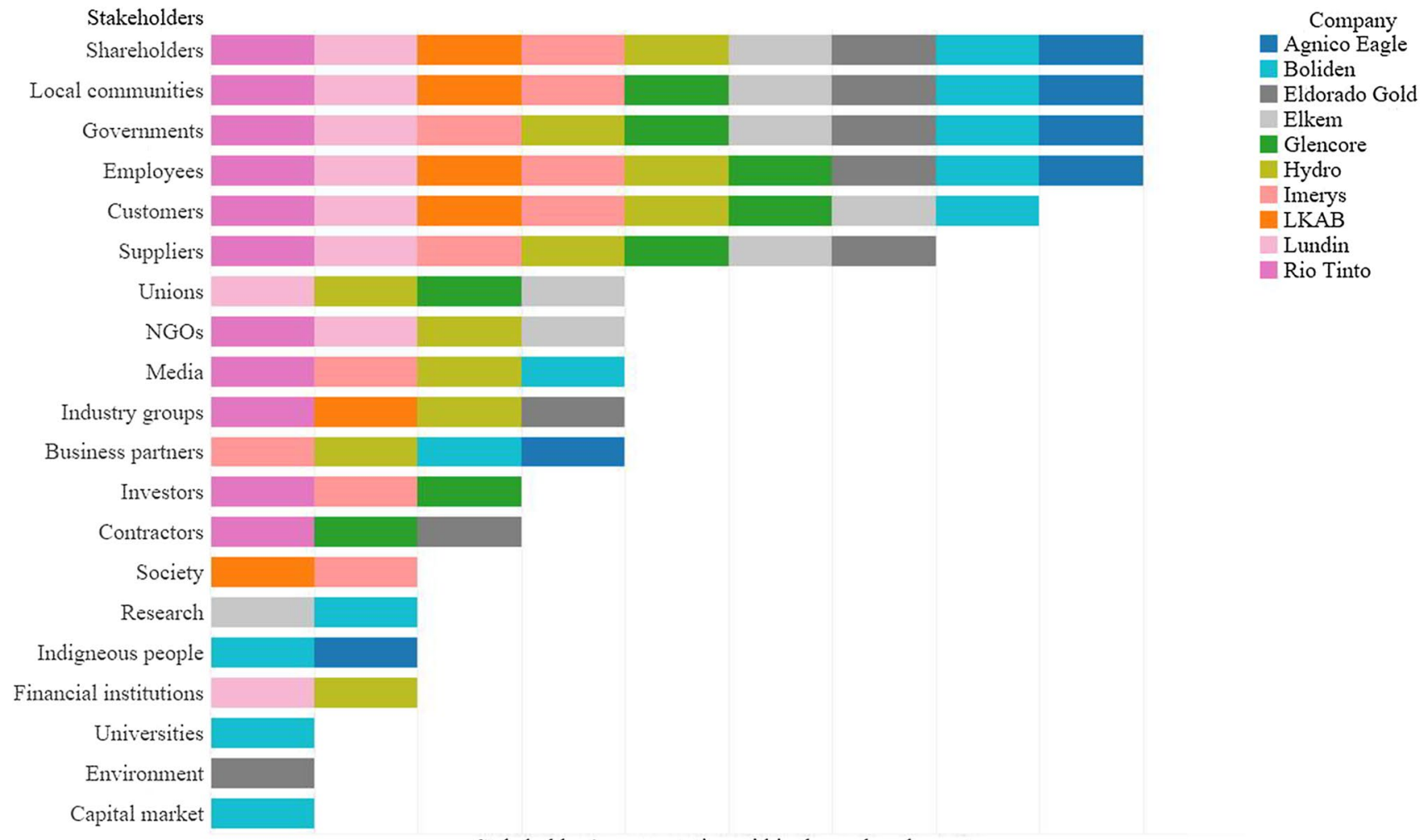

Stakeholders' representation within the analyzed reports

Fig. 5 List of the most and least frequently addressed stakeholder groups. Synthesized by the authors based on the analysis of the data

a critical area to maintain their social license to operate and was based on extensive stakeholder mapping, where the priority stakeholder groups were defined. Each company identified its important group of stakeholders, where shareholders, local communities, governments, and employees were the most common (see Fig. 5).

Local communities were identified as one of the most important stakeholders of the mining companies due to the impact on communities by providing direct employment and indirect jobs carried out by the mining companies' suppliers. Community investments were mostly philanthropic donations to community development, infrastructure, health 
Table 2 Health and safety performance of analyzed mining companies for the 2016-2018 period

\begin{tabular}{|c|c|c|c|c|c|c|c|c|c|c|c|c|}
\hline \multirow[t]{2}{*}{ Health and safety } & \multicolumn{3}{|l|}{ TRIFR } & \multicolumn{3}{|l|}{ LTIFR } & \multicolumn{3}{|c|}{ Fatalities } & \multicolumn{3}{|c|}{$\begin{array}{l}\text { New cases of occu- } \\
\text { pational illnesses }\end{array}$} \\
\hline & 2016 & 2017 & 2018 & 2016 & 2017 & 2018 & 2016 & 2017 & 2018 & 2016 & 2017 & 2018 \\
\hline Agnico Eagle & + & + & - & + & + & - & - & + & + & $n / r$ & $n / r$ & $n / r$ \\
\hline Boliden & + & + & + & + & + & + & + & + & + & $\mathrm{n} / \mathrm{a}$ & $\mathrm{n} / \mathrm{a}$ & $\mathrm{n} / \mathrm{a}$ \\
\hline Eldorado Gold & - & + & - & + & + & + & - & - & + & $n / r$ & $n / r$ & $n / r$ \\
\hline Elkem & + & + & + & $n / r$ & $\mathrm{n} / \mathrm{r}$ & $n / r$ & - & + & + & $\mathrm{n} / \mathrm{a}$ & $\mathrm{n} / \mathrm{a}$ & $\mathrm{n} / \mathrm{a}$ \\
\hline Glencore & + & + & - & - & + & - & - & - & - & + & + & + \\
\hline Hydro & + & - & - & $\mathrm{n} / \mathrm{r}$ & $\mathrm{n} / \mathrm{r}$ & $n / r$ & + & - & - & + & + & - \\
\hline Imerys & + & - & - & + & - & + & - & + & - & + & + & + \\
\hline LKAB & + & - & - & $n / r$ & $\mathrm{n} / \mathrm{r}$ & $n / r$ & + & + & - & $n / r$ & $n / r$ & $\mathrm{n} / \mathrm{r}$ \\
\hline Lundin & + & + & - & + & - & + & + & + & $\uparrow$ & $\mathrm{n} / \mathrm{a}$ & $\mathrm{n} / \mathrm{a}$ & $\mathrm{n} / \mathrm{a}$ \\
\hline Rio Tinto & + & + & - & + & + & - & + & + & - & + & + & - \\
\hline
\end{tabular}

- refers to "negative trends"; + refers to "positive trends"; n/a refers to "not applicable", n/r to "not reported" Created by the authors based on the analysis of the data

and well-being, and education. Mining companies provided scholarships and internships to attract skilled personnel and cooperated with universities and research institutions on various projects.

In the reports, employees were described as key stakeholders, driving forces, and the best ambassadors to attract new employees. The personnel's competence building was done by mandatory in-house training programs and regular performance reviews for further skills and talent development. Mining companies aimed to achieve better gender balance through a workplace without gender-based discrimination or harassment. However, several companies reported on incidents of discrimination or harassment that occurred in the studied period (Boliden, Hydro, LKAB). During the three years, the share of women in companies remained the same or increased slightly, ranging from 11 to $25 \%$.

\subsection{Occupational health and safety}

Health and safety were among the main concerns for the analyzed mining companies whose aim was to operate without injuries. Their safety performance was frequently monitored using several indicators, such as Total Recordable Injury Rate (TRIFR), Lost-Time Injury Frequency (LTIFR), and fatalities (Table 2). Safety improved over the analyzed period, according to the data presented in the reports. Only a few mining firms monitored employees' health by tracking the number of new cases of occupational disease, which indicated a reducing trend in new cases of occupational disease.

\subsection{Environmental issues}

The main environmental material topics in the sustainability reports were energy and greenhouse gas emissions (GHG), water management, waste, and air emissions (Tables 3 and 4). Comparison among the companies was almost impossible, as companies tend to use different units or their multiples for the same indicators, making the presentation of absolute numbers in the tables impossible in a comprehensible manner.

Energy consumption represented one of the significant environmental impacts, with fossil fuels as a highly represented energy source within mining operations, while the share of renewable energy in the energy mix was above average for only a few companies, such as Hydro, Elkem, and Lundin ( $\geq 50 \%)$. Only Hydro and Rio Tinto reduced total energy use in the period from 2016 to 2018.

Decreasing trends in total GHG emissions were noticeable in the data for five companies due to the implementation of energy recovery from excess heat and the replacement of fossil fuels with renewable energy sources. Some companies, however, did not report on air emissions at all. Despite the efforts, most of the companies had increased $\mathrm{SO} 2$ emissions from boosted production or higher sulfur content in the raw material. The dust emissions were lower for the companies that included dust emissions in their reports.

Vast amounts of water are utilized in mineral production; thus, to reduce the impact, companies implement, reuse, and recycle water and use closed systems in production. Compared with 2016, most companies had increased amounts of withdrawn water. The share of reused/recycled water ranged from 10 percent (Hydro) to approximately 200 percent (Lundin). 
Table 3 Environmental performance in energy, GHG emissions and air emissions of analyzed mining companies for the 2016-2018 period

\begin{tabular}{|c|c|c|c|c|c|c|c|c|c|c|c|c|c|c|c|c|c|c|}
\hline \multirow[t]{3}{*}{ Environment } & \multicolumn{6}{|c|}{ Energy } & \multirow{2}{*}{\multicolumn{3}{|c|}{ GHG emission }} & \multicolumn{9}{|c|}{ Air emissions } \\
\hline & \multicolumn{3}{|c|}{ Consumption } & \multicolumn{3}{|c|}{ Renewables } & & & & \multicolumn{3}{|l|}{$\mathrm{SO}_{2}$} & \multicolumn{3}{|l|}{$\mathrm{NO}_{\mathrm{x}}$} & \multicolumn{3}{|l|}{ Dust } \\
\hline & 2016 & 2017 & 2018 & 2016 & 2017 & 2018 & 2016 & 2017 & 2018 & 2016 & 2017 & 2018 & 2016 & 2017 & 2018 & 2016 & 2017 & 2018 \\
\hline Agnico Eagle & - & - & - & $\mathrm{n} / \mathrm{r}$ & $\mathrm{n} / \mathrm{r}$ & $\mathrm{n} / \mathrm{r}$ & + & - & + & $\mathrm{n} / \mathrm{r}$ & $n / r$ & $n / r$ & $\mathrm{n} / \mathrm{r}$ & $\mathrm{n} / \mathrm{r}$ & $n / r$ & $\mathrm{n} / \mathrm{r}$ & $\mathrm{n} / \mathrm{r}$ & $\mathrm{n} / \mathrm{r}$ \\
\hline Boliden & - & - & - & + & + & + & + & + & + & + & - & - & + & - & / & + & - & + \\
\hline Eldorado Gold & - & - & - & $n / r$ & $\mathrm{n} / \mathrm{r}$ & $\mathrm{n} / \mathrm{r}$ & + & - & + & $n / r$ & $n / r$ & $\mathrm{n} / \mathrm{r}$ & $\mathrm{n} / \mathrm{r}$ & $n / r$ & $n / r$ & $\mathrm{n} / \mathrm{r}$ & $\mathrm{n} / \mathrm{r}$ & $\mathrm{n} / \mathrm{r}$ \\
\hline Elkem & - & - & - & + & + & + & - & - & - & - & - & - & + & - & + & + & - & + \\
\hline Glencore & + & + & - & + & + & + & + & + & + & - & - & - & $\mathrm{n} / \mathrm{r}$ & $n / r$ & $n / r$ & $\mathrm{n} / \mathrm{r}$ & $n / r$ & $\mathrm{n} / \mathrm{r}$ \\
\hline Hydro & - & + & + & + & + & + & - & / & + & + & + & + & - & - & + & + & + & + \\
\hline Imerys & - & - & - & + & / & / & - & - & - & - & - & - & - & - & - & $\mathrm{n} / \mathrm{r}$ & $n / r$ & $n / r$ \\
\hline LKAB & - & - & + & - & - & - & - & - & - & + & - & / & + & + & + & - & + & / \\
\hline Lundin & - & - & - & + & + & + & + & - & - & $\mathrm{n} / \mathrm{r}$ & $n / r$ & $n / r$ & $\mathrm{n} / \mathrm{r}$ & $n / r$ & $n / r$ & $\mathrm{n} / \mathrm{r}$ & $n / r$ & $n / r$ \\
\hline Rio Tinto & - & + & + & + & + & + & + & + & + & - & + & + & - & + & + & + & + & + \\
\hline
\end{tabular}

- refers to "negative trends"; + refers to "positive trends"; / refers to "no change"; n/a refers to "not applicable", n/r to "not reported". Created by the authors based on the analysis of the data

Table 4 Environmental performance in water, waste, and land use of analyzed mining companies for the 2016-2018 period

\begin{tabular}{|c|c|c|c|c|c|c|c|c|c|c|c|c|c|c|c|c|c|c|}
\hline \multirow[t]{3}{*}{ Environment } & \multicolumn{6}{|l|}{ Water } & \multicolumn{6}{|l|}{ Waste } & \multicolumn{6}{|c|}{ Land use } \\
\hline & \multicolumn{3}{|c|}{ Withdrawal } & \multicolumn{3}{|c|}{ Recycled/reused } & \multicolumn{3}{|c|}{ Generated } & \multicolumn{3}{|c|}{ Recycled/reused } & \multicolumn{3}{|c|}{ Disturbed } & \multicolumn{3}{|c|}{ Rehabilitated } \\
\hline & 2016 & 2017 & 2018 & 2016 & 2017 & 2018 & 2016 & 2017 & 2018 & 2016 & 2017 & 2018 & 2016 & 2017 & 2018 & 2016 & 2017 & 2018 \\
\hline Agnico Eagle & - & - & - & $\mathrm{n} / \mathrm{r}$ & $n / r$ & $\mathrm{n} / \mathrm{r}$ & + & - & + & + & + & + & $\mathrm{n} / \mathrm{r}$ & $\mathrm{n} / \mathrm{r}$ & $\mathrm{n} / \mathrm{r}$ & $\mathrm{n} / \mathrm{r}$ & $\mathrm{n} / \mathrm{r}$ & $\mathrm{n} / \mathrm{r}$ \\
\hline Boliden & - & / & / & + & - & + & - & - & - & + & + & + & - & + & - & + & - & + \\
\hline Eldorado Gold & + & + & + & + & + & + & $\mathrm{n} / \mathrm{r}$ & $\mathrm{n} / \mathrm{r}$ & $\mathrm{n} / \mathrm{a}$ & $\mathrm{n} / \mathrm{r}$ & $\mathrm{n} / \mathrm{r}$ & $\mathrm{n} / \mathrm{r}$ & $\mathrm{n} / \mathrm{a}$ & $\mathrm{n} / \mathrm{a}$ & + & $\mathrm{n} / \mathrm{a}$ & $\mathrm{n} / \mathrm{a}$ & + \\
\hline Elkem & $\mathrm{n} / \mathrm{a}$ & $n / a$ & $n / a$ & $\mathrm{n} / \mathrm{r}$ & $\mathrm{n} / \mathrm{r}$ & $\mathrm{n} / \mathrm{r}$ & $\mathrm{n} / \mathrm{a}$ & $\mathrm{n} / \mathrm{a}$ & $\mathrm{n} / \mathrm{a}$ & $\mathrm{n} / \mathrm{r}$ & $\mathrm{n} / \mathrm{r}$ & $\mathrm{n} / \mathrm{r}$ & $\mathrm{n} / \mathrm{r}$ & $\mathrm{n} / \mathrm{r}$ & $\mathrm{n} / \mathrm{r}$ & $\mathrm{n} / \mathrm{r}$ & $n / r$ & $n / r$ \\
\hline Glencore & - & + & - & + & - & + & - & - & - & $\mathrm{n} / \mathrm{r}$ & $\mathrm{n} / \mathrm{r}$ & $\mathrm{n} / \mathrm{r}$ & $\mathrm{n} / \mathrm{r}$ & $n / r$ & $\mathrm{n} / \mathrm{r}$ & $\mathrm{n} / \mathrm{r}$ & $n / r$ & $n / r$ \\
\hline Hydro & - & - & - & - & - & - & + & + & + & + & + & + & - & - & - & + & + & + \\
\hline Imerys & - & - & - & + & + & + & - & - & - & + & + & - & + & + & + & - & - & - \\
\hline LKAB & $n / r$ & $n / r$ & $n / r$ & $n / r$ & $n / r$ & $n / r$ & - & - & - & $\mathrm{n} / \mathrm{r}$ & $n / r$ & $n / r$ & $n / r$ & $n / r$ & $n / r$ & $\mathrm{n} / \mathrm{r}$ & $n / r$ & $n / r$ \\
\hline Lundin & + & + & + & + & + & + & + & - & - & + & + & + & - & - & - & - & - & - \\
\hline Rio Tinto & - & - & + & + & + & - & + & + & + & $\mathrm{n} / \mathrm{r}$ & $\mathrm{n} / \mathrm{r}$ & $\mathrm{n} / \mathrm{r}$ & - & + & - & - & + & + \\
\hline
\end{tabular}

- refers to "negative trends"; + refers to "positive trends"; / refers to "no change"; n/a refers to "not applicable", n/r to "not reported". Created by the authors based on the analysis of the data

The generation of waste from mining operations increased for the majority of companies, while half of them did not present data for reused or recycled waste. Barren rock and tailings were used as backfill in underground mines, as a construction material, and in cement production. Elkem used collected micro silica as a byproduct, while Hydro and Boliden recovered metals from process waste.

Mining uses large land areas for mining, exploration, and the construction of the mining infrastructure. Boliden, Imerys, Hydro, and Rio Tinto used two land-use indicators, namely, total disturbed surface area and total rehabilitated area. Despite the restoration activities, the rehabilitated area per year was much lower than the affected area.

\subsection{Integration of the SDGs into the core business}

Mining companies' sustainability work is based on their own established norms and values, as well as on the UN Global Compact principles and the SDGs. Implementation of the SDGs into the sustainability reports considerably improved over the three-year study period. In 2016, only Glencore, Hydro, Lundin, and Rio Tinto began to align their sustainability strategies with the SDGs. By the 2018 reporting year, all the mining companies adopted SDGs as a part of their business strategy. Their contribution to the SDGs is explained either in special sections within the report 
Table 5 Sustainable Development Goals were referred to in the analyzed reports

\begin{tabular}{|l|l|l|l|l|l|l|l|l|l|l|l|l|l|l|l|l|l|}
\hline SDG & $\mathbf{1}$ & $\mathbf{2}$ & $\mathbf{3}$ & $\mathbf{4}$ & $\mathbf{5}$ & $\mathbf{6}$ & $\mathbf{7}$ & $\mathbf{8}$ & $\mathbf{9}$ & $\mathbf{1 0}$ & $\mathbf{1 1}$ & $\mathbf{1 2}$ & $\mathbf{1 3}$ & $\mathbf{1 4}$ & $\mathbf{1 5}$ & $\mathbf{1 6}$ & $\mathbf{1 7}$ \\
\hline Agnico Eagle & + & + & + & + & + & + & & + & + & + & + & + & + & + & + & + & + \\
\hline Boliden & + & & + & + & + & + & + & + & & + & + & + & + & + & + & + & + \\
\hline Eldorado Gold & & & + & & + & + & & + & + & & & + & & & & & \\
\hline Elkem & & & + & & & & + & + & + & & & & + & & & + & \\
\hline Glencore & & & + & & & + & & + & & + & & + & + & + & + & + & + \\
\hline Hydro & & & & + & & & & + & + & & & + & + & + & + & + & \\
\hline Imerys & & & + & + & + & + & & + & & & & + & + & & + & + & \\
\hline LKAB & & & & & + & & + & + & + & & + & & + & & + & + \\
\hline Lundin & & & + & & + & & + & + & + & + & & + & + & & & + & + \\
\hline Rio Tinto & & & & + & + & + & & + & & + & + & & + & & & & + \\
\hline
\end{tabular}

Each color represents the color of the specific Sustainable Development Goals

Created by the authors based on the analysis of the data

or directly linked to the materiality topics. Most companies identified several specific SDGs relevant to the most substantial impacts from mining activities based on their assessment. However, the explanations were too general without profound relation to the SDGs and their interconnections, trade-offs, and synergies or defined objectives linked to the SDG targets. Rio Tinto and Lundin expressed their further efforts to integrate SDGs into the business strategy in the reports.

The results from all referred SDGs from the reports are presented in Table 5. The only mutual SDG for all companies was Goal number 8, Decent work, and economic growth, followed by SDG 3 Good health and well-being and SDG 13 Climate action. Other relevant SDGs within the studied reports were SDG 16 Peace, justice, and strong institutions, SDG 5 Gender equality, SDG 6 Clean water and sanitation, SDG 9 Industry, innovation and infrastructure, SDG 10 Reduced inequalities, SDG 12 Responsible consumption and production, and SDG 15 Life on land. SDG 1 No poverty and SDG 2 Zero hunger were not well represented in the analyzed sustainability reports.

\subsection{Institutional drivers of sustainability of European mining companies}

All the companies stated that they had been publishing sustainability reports for a longer period. The following findings based on the qualitative content analysis of the reports indicate that European mining companies act under pressure from international initiatives such as the UNGC, industry associations, the European Union, governments, stakeholders, and partnerships to address sustainability issues. To support the results, for each identified driver, the segments from the 2018 reports are included.

International initiatives such as UNGC, SDSs, and GRI are highlighted in the reports as a base for the company's sustainability business strategy, for example:

Boliden's sustainability work is based on our own norms and values, as well as international guidelines and targets, such as the UN Global Compact and the UN Sustainable Development Goals (Boliden 2018, p.8).

Industry associations encourage companies to apply the best practices and obligate their members to follow their principles and requirements (ICMM):

Involvement with memberships and industry associations enables Lundin Mining to keep current regarding matters of public policy, emerging sector and sustainability trends, regulatory updates, stakeholder interests, and the sharing of industry best practices (Lundin 2018, p.12). 


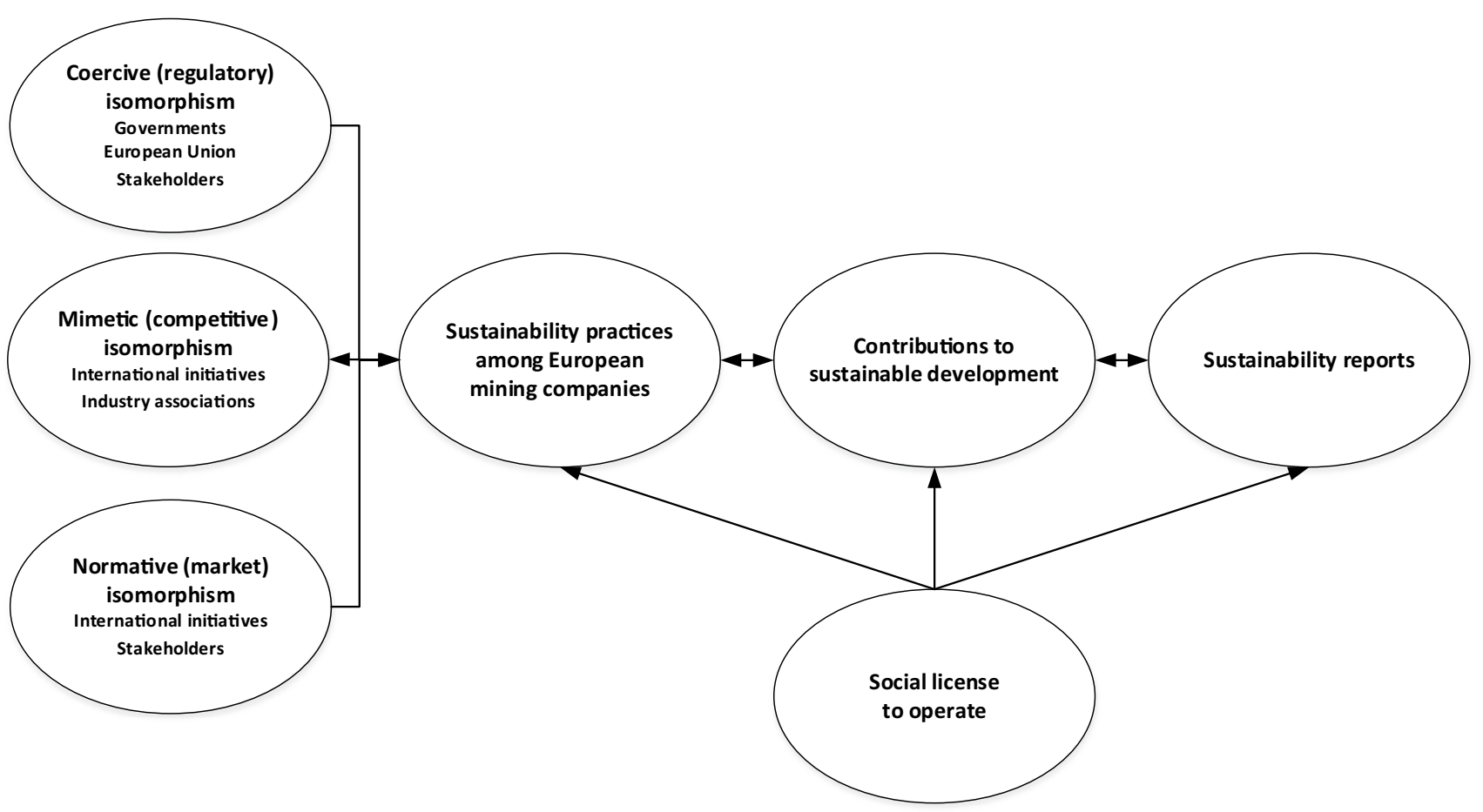

Fig. 6 Synthesis of the findings using insight from institutional theory. Created by the authors based on the analysis of the data

Companies stated that respecting the laws and regulations on government and the EU level is one of the main matters for consistent mining operations:

Our operations, including the impact we have on the surrounding area, are regulated by Swedish and European legislation and by the permits that apply to each part of the operations (LKAB 2018, p. 55).

Various stakeholders (Fig. 5), especially local communities, were a highly influential force requiring that mining companies implement actions to mitigate negative impacts such as dust, noise, and heavy traffic and maintain social dialogue:

Through building constructive and transparent relationships with our stakeholders, we can strengthen our approaches and improve how we operate (Glencore 2018, p. 14).

Social license to operate from local communities are emphasized as the main concern for the analyzed mining companies, as they secure their acceptance for mining activities:

The goal is to gain community understanding and acceptance for our mining activities and projects (Agnico Eagle 2018, p. 48).

\section{Discussion}

The overall aim of this research was to analyze, compare and critically evaluate sustainability reports of European mining companies for the 2016-2018 period to determine the drivers for implementation of sustainability practices and to assess performance based on their reported data and the integration of SDGs.

Figure 6 synthesizes the key findings of the study showing how institutional drivers influence sustainability practices among European mining companies and their contribution to sustainable development, as presented in their sustainability reports. Compliance with the regulations and permits is seen as a fundamental driver of the analyzed mining companies to maintain successful operations, together with additional significant pressure, in the form of community acceptance, namely, the social license to operate. Additionally, the figure shows how reporting on sustainability issues may lead to additional improvements in terms of contributions to sustainable development, such as an increased emphasis on the SDGs evident from the analysis and in the environmental and social sustainability practices of European mining 
companies. These improvements can, in turn, further alter institutional drivers, such as through peer pressure among companies in the same sector. All these aspects are discussed further in what follows.

\subsection{Institutional drivers for implementation of sustainability practices in European mining}

As the analyzed companies had been publishing sustainability reports prior to the period included in this study, it can be argued that the pressures for such disclosure relate to normative isomorphism [69]. The positive trend of mining companies joining the UNGC was influenced by mimetic pressures [67], as the UNGC is a voluntary initiative; therefore, no regulation obliges companies to join it.

The mining industry has been under pressure to act responsibly regarding environmental and social issues by several external drivers [51, 62]. Participation in internationally recognized sustainability initiatives determines the company's commitment to the implementation of sustainable practices [69] and can be identified as one of the main isomorphic pressures to institutionalize CSR in business. Furthermore, membership in industry associations encourages companies to apply and share best practices in the industry $[67,73]$.

National governments and legislation are another coercive factor, as governments issue mining permits to operate on which companies must comply and can force changes in sustainability activities through environmental and social laws, taxation systems, labor practices, and corporate governance regulations [65]. EU legislation is also recognized as one of the regulatory forces influencing mining companies in Europe to align their operations and polices to new regulations, such as the REACH Directive on Regulation on Registration, Evaluation, Authorization and Restriction of Chemicals, EU waste regulations, and various others [57].

In general, stakeholders impose coercive and normative pressures on companies $[65,72]$ by forcing them to improve their performance to maintain their social license to operate $[45,74]$. These findings support previous research on sustainability drivers in organizations, which also identified governments, regulations and legislation, stakeholders' engagement $[51,71,72]$, and industry associations [73] as external drivers together with a social license to operate and sustainability initiatives as additional pressures $[51,71]$.

\subsection{Mining contribution to sustainable development and the assessment of the performance}

Significant disparity is evident from the presented results related to the differences between the reports in terms of the indicators utilized, details of the disclosed data, and metrics supporting the findings of previous studies on the difficulty in comparing reported performance between companies [58].

The findings support the results of a previous review of sustainability practices in the mining industry [38], i.e., that the Code of Conduct, together with sustainability reports and community engagement, predominantly characterizes sustainability management. Maintaining a strong and open dialogue with stakeholders and their engagement is an important objective for mining companies to secure a social license to operate [56]. Local communities were recognized as one of the most crucial stakeholders [65] represented in specially developed protocols, community monitoring programs, and community relations teams [38]. Among the key stakeholder classifications, only Boliden identified the environment as the priority stakeholder. Considering the significant negative environmental impact of mining operations (Table 1), it should arguably also be recognized as a key stakeholder by other companies [82]. Following the concept of sustainable development [83], future generations are important stakeholders recognized by local communities in previous studies [46] and are affected by the present decisions of companies that they cannot influence [82].

The most important stakeholders for mining companies are their employees; therefore, great efforts are made to attract skilled new employees and to retain existing employees. Due to operations in remote areas, high risk for employees and often the negative image of mining [41], they struggle to attract highly qualified and locally available skilled people [44]. Even though diversity is highlighted in the reports, especially gender equality, the results show that the mining industry is still male dominated $[27,42]$ with a steady low share of women employees. Additionally, cases of harassment and discrimination evidenced in this research confirm other studies' outcomes [43] that women workers in the mining industry still experience discrimination. These issues could be mitigated through an increased emphasis on social sustainability, including good working conditions, employment opportunities and gender equality [27, 28].

The results in health and safety performance suggest that progress is evident in reduced injuries in the workplace due to safety training, programs, risk assessment and implemented technology [40,41]. However, due to fatalities, there is a necessity for a stronger safety culture combined with the best technologies to prevent accidents [41], including safety culture programs and certification. 
Energy presents a huge part of mining impact [37], and most of the analyzed companies had increased their energy consumption during the study period. Mining companies should not just be the providers of minerals for a low-carbon future but also be leaders in efficient renewable energy use and energy savings in the production and use of secondary raw materials $[4,18]$. The inclusion of these considerations would ensure a more genuine mining contribution to sustainable development based on enabling a renewable energy transition while mitigating the negative impacts of current mining operations.

Half of the studied companies decreased their GHG emissions by using excess heat, recycling, renewable energy sources and improved energy efficiency [32]. Nevertheless, targets for reducing carbon emissions were not ambitious, and moreover, 40 percent of the companies did not have any targets to reduce GHG emissions [35]. The findings indicate that companies are far from meeting the Paris Agreement goals [11] and the EU's objective of becoming climate neutral by decarbonizing the energy sector [14]. Although air pollution from mining has a great impact on the environment [33], this impact was not thoroughly covered by most of the companies.

Even though most of the water was recycled and reused in the operations, not all the companies disclosed data on recycled water [34]. To contribute to the SDGs [13], the EU's Green Deal, and the sustainable supply of raw materials [4], European mining companies could pay more attention to utilizing the generated waste to extract valuable secondary minerals through the circular economy model, as they have great potential to contribute to the limited mineral supply and generate profit $[17,19]$ while reducing their energy input, environmental risks, and overall environmental footprint [20]. The results demonstrate that the efforts to restore disturbed land area are significantly low; therefore, the implementation of integrated mine closure during the operation phase would result in better environmental protection and transparent stakeholder engagement [84]. Furthermore, biodiversity issues should be addressed through a more holistic approach due to the European Commission's [14] recognition of biodiversity conservation as one of the essential activities to achieve a climate-neutral EU and companies' commitment to the SDGs. Overall, to promote strong environmental sustainability, mining companies should focus on the efficient use of resources and strengthen the implementation of renewable energy sources, tackle climate change and biodiversity issues, and waste recovery [25,26], which was only partially done by a minority of the analyzed companies [26].

\subsection{Integration of the SDGs based on the companies' sustainability reports analysis}

From the results related to the SDGs, mining companies made considerable progress in linking their sustainability activities to the SDGs from several firms in 2016 to citing the SDGs in all analyzed sustainability reports two years later [51]. Only one Goal, SDG 8 on decent work and economic growth, was common for all companies, which demonstrates that these companies recognize their economic contributions as one of the most crucial segments of their impacts on sustainable development [59]. Most of the companies associated one or more SDGs with the report's materiality topic or indicators, while some had separate sections related to the identified SDGs. What is lacking in some reports is an evident explanation of the contribution of the associated SDGs and activities [54, 55]. To enhance SDG integration, companies could set and align their short-term and long-term objectives to SDG targets and indicators. Likewise, contributions to the SDGs could be more comprehensive, with exact activities connected to the Goals instead of general explanations [59]. The findings indicate the use of SDGs such as "rainbow washing" and "cherry-picking" to make the company's actions look better by choosing only the Goals where they have a positive impact instead of truly engaging with the issues covered by the SDGs [59]. However, considering that the SDGs are a relatively new topic and that the results suggest that most of the analyzed companies started aligning their business strategies to the SDGs in 2017 or 2018, a longer period of time is required for mining companies to fully implement the SDGs in their business strategy and sustainability disclosures [59].

\section{Conclusions}

The results of this research offer a unique contribution to understanding the sustainability activities of mining companies in Europe, the external drivers that motivate them to engage in these activities and their implementation of the SDGs in sustainability reports. This study addressed a research gap of limited academic research conducted on sustainable development regarding the European mining industry. International initiatives, industry associations, the EU, national governments, and external stakeholders are recognized as the forces pressuring the mining industry in Europe to implement 
sustainability practices. Therefore, this research provides new insight into the drivers of sustainability practices in the mining industry based on insights gleaned from institutional theory. Since the EU recognized the extractive industry as one of the key partners in the realization of the Green Deal, the findings are relevant to European policymakers responsible for sustainability regulations and as a benchmark for policymakers in other regions. The research reported here is also applicable to mining companies, to learn from their peers, to reduce negative impact, and to implement best practices.

Mining companies in Europe implement various actions to reduce their impact, ranging from stakeholder engagement and the application of new technologies to employee training and skill development. However, there is a lack of progress in renewable energy, generated waste utilization, circular economy contributions, and higher gender equality. Despite their progress in the implementation of the SDGs regarding sustainability reporting, disclosed contributions were too general without detailed explanation and set objectives lacked relation with the SDGs' key performance indicators. Moreover, the overall sustainability contribution of the analyzed companies lacked a holistic approach to promote strong sustainability instead of mostly focusing on minimizing the impacts of their operations.

Perhaps the most important limitation of the study is that the analysis is based on self-reported data that are used as a measure of company performance. The lack of previous studies in the field of sustainability reporting within the European mining industry was also a limiting factor in conducting the research. Regardless of the uniform use of similar sustainable reporting standards, there are some obstacles to the comparability of the studied reports. Due to different materiality assessments, some materiality topics were not disclosed, such as biodiversity, and the GRI Content Index was missing in some reports. The performance indicators on which companies report differ from using one to several indicators related to the same subject or different measuring units for the same indicators, such as either joules (GJ, $\mathrm{TJ}$ ) or watthours ( $\mathrm{kWh}, \mathrm{GWh}$ ) for energy consumption. While some companies presented exact numbers in the forms of tables and graphs and data for different geographical locations and periods, others disclosed numbers only for the reporting year; hence, the reader cannot gain an overall view of whether the company improved or not. Additionally, the geographical distribution of mines and varying exploited raw material may cause comparability issues. This lack of comparability among companies' reports even when they use the same reporting frameworks constitutes a limitation and an important finding pointing to the need for increased standardization in reporting.

Future studies on this topic should explore further implementation and the synergies and trade-offs between the SDGs among mining companies in Europe, especially since the analyzed period might have been too short to detect significant progress. Furthermore, different research methods or data sources could be used, such as interviews with sustainability committees or key stakeholders, to provide a broader view and better understanding of the effectiveness of the implemented sustainability activities and practices, as reporting frameworks largely address "the past", while sustainability needs strategic, future-oriented, and long-term thinking. Additionally, the contribution of mining to the low carbon economy and its role as an enabler of green transformation is another topic to be addressed in the future. Moreover, economic and internal drivers for the implementation of sustainability practices could be explored, including the drivers for improving SDGs, which may be the result of improved production efficiency and consequently profitability. Finally, this research offers a model for further studies, not just for Europe, and can serve as a comparative tool for future research on progress towards sustainable development.

\begin{abstract}
Authors' contributions All authors contributed to the study conception and design. Material preparation, data collection and analysis were performed by Al. The first draft of the manuscript was written by Al and all authors commented on previous versions of the manuscript. All authors read and approved the final manuscript. Al: conceptualization, methodology, investigation, formal analysis, writing, original draft preparation, reviewing and editing, visualization. NMS: conceptualization, supervision, validation, reviewing and editing, visualization, corresponding author. LJ: conceptualization, supervision, validation, reviewing and editing, visualization, project administration. All authors read and approved the final manuscript.
\end{abstract}

\title{
Declarations
}

Competing interests The authors declare no competing interests.

Open Access This article is licensed under a Creative Commons Attribution 4.0 International License, which permits use, sharing, adaptation, distribution and reproduction in any medium or format, as long as you give appropriate credit to the original author(s) and the source, provide a link to the Creative Commons licence, and indicate if changes were made. The images or other third party material in this article are included in the article's Creative Commons licence, unless indicated otherwise in a credit line to the material. If material is not included in the article's Creative Commons licence and your intended use is not permitted by statutory regulation or exceeds the permitted use, you will need to obtain permission directly from the copyright holder. To view a copy of this licence, visit http://creativecommons.org/licenses/by/4.0/. 


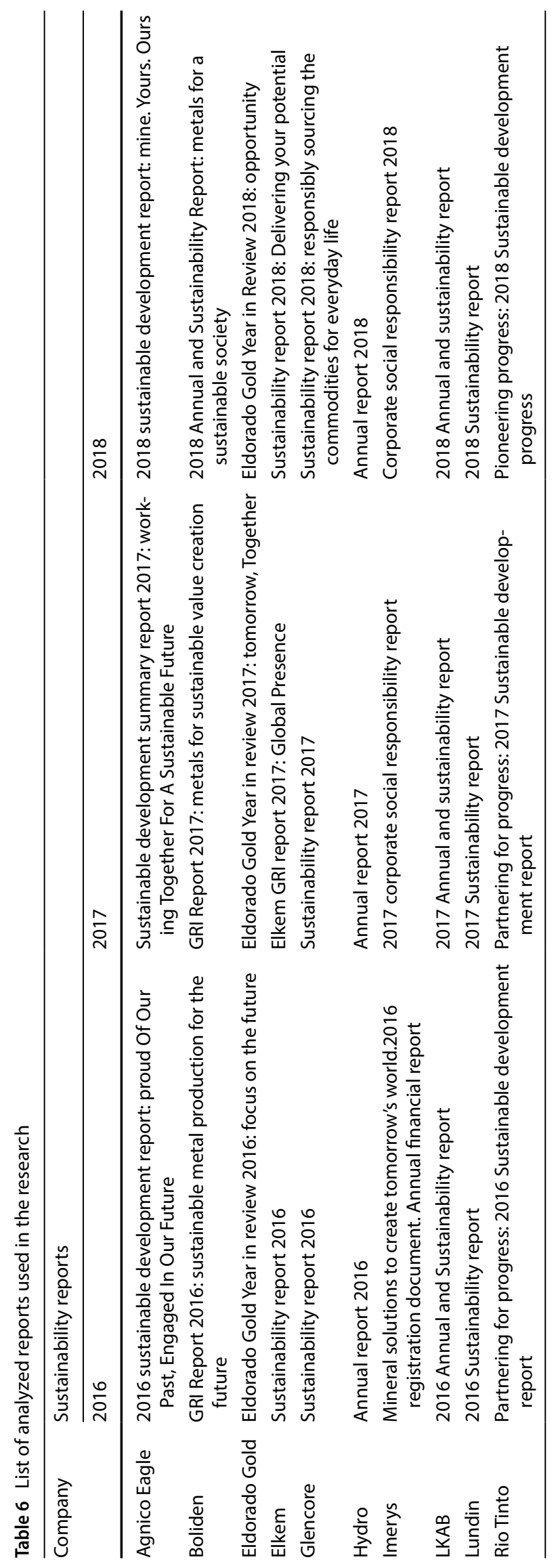




\section{Appendix 1}

\section{See Table 6.}
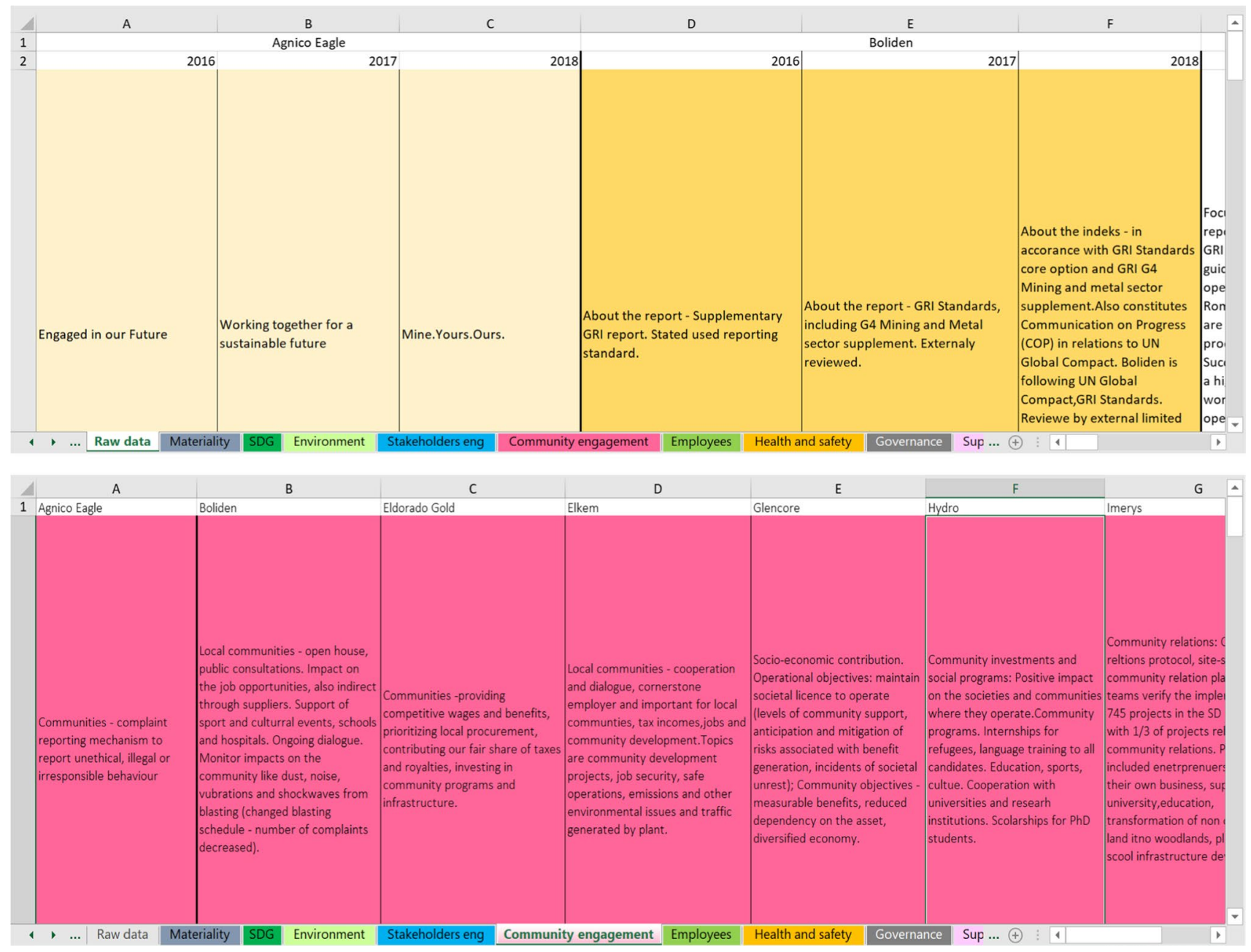

Fig. 7 Examples of the content analysis process from the Excel sheet-raw data and subcategory community engagement

\section{Appendix 2}

\section{See Fig. 7.}

\section{References}

1. Hartman HL, Mutmansky JM. Introductory mining engineering. Hoboken, N.J: Wiley; 2002.

2. Lech J. Flint Mining. Special Theme Issue: Archaeologia Polonia; 1995. p. 33.

3. European commission. The raw materials initiative-meeting our critical needs for Growth and jobs in Europe. 2008. http://www.eurom ines.org/files/what-we-do/sustainable-development-issues/raw-materials-initiative.pdf. Accessed 20 Nov 2019.

4. European Commission. Industrial minerals. 2019. https://ec.europa.eu/growth/sectors/rawmaterials/industries/minerals/industrial_en. Accessed 20 Nov 2019.

5. Nurmi P, Molnar F. The future of metal minerals mining in the EU. Eur Geol. 2014;37:12-9.

6. Commission E. Metallurgy made in and for Europe. The Perspective of Producers and End-Users Roadmap: Publications Office of the European Union; 2014. 
7. Parameswaran K. Sustainability considerations in innovative process development. Innovative process development in metallurgical industry. Spring Inter Pub. 2016. https://doi.org/10.1007/978-3-319-21599-0_13.

8. Kapelus P. Mining, corporate social responsibility, and the "community": the case of Rio Tinto, Richards Bay minerals and the Mbonambi. J Bus Ethics. 2002;39:275-96. https://doi.org/10.1023/A:1016570929359.

9. Mason L, Prior T, Mudd G, Giurco D. Availability, addiction, and alternatives: three criteria for assessing the impact of peak minerals on society. J Clean Prod. 2011;19(9-10):958-66. https://doi.org/10.1016/j.jclepro.2010.12.006.

10. Mudd GM. Gold mining in Australia: linking historical trends and environmental and resources sustainability. Enviro Sci Pol. 2007;10(78):629-44. https://doi.org/10.1016/j.envsci.2007.04.006.

11. McKinsey \& Company. Climate risk and decarbonization: What every mining CEO needs to know. 2020. https://www.mckinsey.com/busin ess-functions/sustainability/our-insights/climate-risk-and-decarbonization-what-every-mining-ceo-needs-to-know\#. Accessed 15 Jun 2020.

12. Ali S, Giurco D, Arndt N, et al. Mineral supply for sustainable development requires resource governance. Nature. 2017;543:367-72. https:// doi.org/10.1038/nature21359.

13. Columbia Center on Sustainable Investment (CCSI), UNDP, UN Sustainable Development Solutions Network (SDSN), \& World Economic Forum. White Paper-Mapping Mining to the Sustainable Development Goals: An Atlas. 2016. www.jstor.org/stable/resrep15880. Accessed 20 Nov 2019.

14. European Commission. Communication from the commission to the European parliament, the European council, the council, the European economic and social committee and the committee of the regions: The European Green Deal. 2019. https://ec.europa.eu/info/sites/info/ files/european-green-deal-communication_en.pdf. Accessed 10 Aug 2020.

15. Krausmann F, Gingrich S, Eisenmenger N, Erb KH, Haberl H, Fischer Kowalski M. Growth in global materials use, GDP and population during the 20th century. Ecol Econ. 2009;68:2696-705. https://doi.org/10.1016/j.ecolecon.2009.05.007.

16. Henckens MLCM, Driessen PPJ, Worrell E. Metal scarcity and sustainability, analyzing the necessity to reduce the extraction of scarce metals. Resour Cons Recyc. 2014;93:1-8. https://doi.org/10.1016/j.resconrec.2014.09.012.

17. Wellmer FW, Hagelüken C. The feedback control cycle of minerals supply, increase of raw materials efficiency, and sustainable development. Minerals. 2015;5:815-36. https://doi.org/10.3390/min5040527.

18. Hagelüken C, Lee-Shin JU, Carpentier A, Heron C. The EU circular economy and its relevance to metal recycling. Recycling. 2016;1 (2):24253. https://doi.org/10.3390/recycling1020242.

19. Zhao Y, Zang L, Li Z, Qin J. Discussion on the model of mining circular economy. En Proc. 2012;16:438-43. https://doi.org/10.1016/j.egypro. 2012.01.071.

20. Lottermoser BG. Recycling, reuse and rehabilitation of mine wastes. Elements. 2011;7:405-10. https://doi.org/10.2113/gselements.7.6. 405.

21. Huisman J, Botezatu I, Herreras L, Liddane M, Hintsa J, di Cortemiglia LV, Leroy P, Vermeersch E, Mohanty S, van den Brink S, et al. Countering WEEE Illegal Trade (CWIT) Summary Report, Market Assessment, Legal Analysis, Crime Analysis and Recommendations Roadmap. 2015.

22. Fonseca A, McAllister ML, Fitzpatrick P. Sustainability reporting among mining corporations: a constructive critique of the GRI approach. J Clean Prod. 2014;2014:84. https://doi.org/10.1016/j.jclepro.2012.11.050.

23. Gorman M, Dzombak D. A review of sustainable mining and resource management: transitioning from the life cycle of the mine to the life cycle of the mineral. Res Cons Recyc. 2018;137:281-91. https://doi.org/10.1016/j.resconrec.2018.06.001.

24. Giurco D, Cooper C. Mining and sustainability: asking the right questions. Min Eng. 2012;29:3-12. https://doi.org/10.1016/j.mineng.2012. 01.006 .

25. Neto OGC, Pinto LFR, Amorim MPC, Giannetti BF, Almeida CMVB. A framework of actions for strong sustainability. J Clean Prod. 2018;196:1629-43. https://doi.org/10.1016/j.jclepro.2018.06.067.

26. Tost $M$, Hitch $M$, Chandurkar V, Moser P, Feiel S. The state of environmental sustainability considerations in mining. J Clean Prod. 2018;182:969-77. https://doi.org/10.1016/j.jclepro.2018.02.051.

27. Segerstedt $E$, Abrahamsson L. Diversity of livelihoods and social sustainability in established mining communities. Extr Ind Soc. 2019;6(2):610-9. https://doi.org/10.1016/j.exis.2019.03.008.

28. Johannsdottir L, Olafsson S, Davidsdottir B. Insurance perspective on talent management and corporate social responsibility: a case study of nordic insurers. J Manag Sustain. 2014. https://doi.org/10.1108/JOCM-12-2013-0238.

29. Azapagic A. Developing a framework for sustainable development indicators for the mining and minerals industry. J Clean Prod. 2004;12(6):639-62. https://doi.org/10.1016/S0959-6526(03)00075-1.

30. Moran CJ, Kunz NC. Sustainability as it pertains to minerals and energy supply and demand: a new interpretative perspective for assessing progress. J Clean Prod. 2014;84:16-26. https://doi.org/10.1016/j.jclepro.2014.09.008.

31. Wingard HC, Vorster Q. Financial performance of environmentally responsible South African listed companies. Meditari Account Res. 2001;9(1):313-32. https://doi.org/10.1108/1022252920010017.

32. McLellan BC, Corder GD, Giurco DP, Ishihara KN. Renewable energy in the minerals industry: a review of global potential. J Clean Prod. 2012;32:32-44. https://doi.org/10.1016/j.jclepro.2012.03.016.

33. Asif Z, Chen Z. Environmental management in North American mining sector. Env Sci Poll Res Int. 2016;23(1):167-79. https://doi.org/10. 1007/s11783-019-1156-x.

34. Mudd GM. Sustainability reporting and water resources: a preliminary assessment of embodied water and sustainable mining. Mine Water Environ. 2008;27:136-44. https://doi.org/10.1007/s10230-008-0037-5.

35. Sonter L, Ali S, Watson J. Mining and biodiversity: key issues and research needs in conservation science. Proc R Soc B Bio Sci. 2018. https:// doi.org/10.1098/rspb.2018.1926.

36. Lèbre $E$, Corder GD, Golev A. Sustainable practices in the management of mining waste: a focus on the mineral resource. Miner Eng. 2017;107:34-42. https://doi.org/10.1016/j.mineng.2016.12.004.

37. Nasirov S, Agostini CA. Mining experts' perspectives on the determinants of solar technologies adoption in the Chilean mining industry. Renew Sust En Rev. 2018;95:194-202. https://doi.org/10.1016/j.rser.2018.07.038. 
38. Ranängen $\mathrm{H}$, Zobel T. Revisiting the 'how' of corporate social responsibility in extractive industries and forestry. J Clean Prod. 2014;84(1):299-312. https://doi.org/10.1016/j.jclepro.2014.02.020.

39. Endl $A$, Tost $M$, Hitch $M$, Moser $P$, Feiel $S$. Europe's mining innovation trends and their contribution to the sustainable development goals: blind spots and strong points. Resour Pol. 2019. https://doi.org/10.1016/j.resourpol.2019.101440.

40. Hebblewhite B. Mine safety-through appropriate combination of technology and management practice. Proc Earth Planet Sci. 2009;1:13-9. https://doi.org/10.1016/j.pro.2009.09.005.

41. Loow J, Nygren M. Initiatives for increased safety in the Swedish mining industry: studying 30 years of improved accident rates. Saf Sci. 2019;117:437-46. https://doi.org/10.1016/j.ssci.2019.04.043.

42. Lahiri-Dutt K, Macintyre M. Women miners in developing countries: pit women and others. Gend Work Org. 2006;16(2):285-7. https:// doi.org/10.1177/004908570703700403.

43. Botha D. Women in mining: an assessment of workplace relations struggles. J Soc Sci. 2016;46(3):251-63. https://doi.org/10.1080/ 09718923.2016 .11893533$.

44. Mancini \& Sala. Social impact assessment in the mining sector: review and comparison of indicators frameworks. Res Pol. 2018;57:98111. https://doi.org/10.1016/j.resourpol.2018.02.002.

45. Ranängen $\mathrm{H}$, Lindman A. A path towards sustainability for the Nordic mining industry. J Clean Prod. 2017;151:43-52. https://doi.org/ 10.1016/j.jclepro.2017.03.047.

46. Suopajärvi L, Poelzer GA, Ejdemo T, Klyuchnikova E, Korchak E, Nygaard V. Social sustainability in northern mining communities: a study of the European Northand and Northwest Russia. Res Pol. 2016;47:61-8. https://doi.org/10.1016/j.resourpol.2015.11.004.

47. Boutilier R, Thomson I. Modeling and measuring the social license to operate: fruits of a dialog between theory and practice. Mine Manag: Inter; 2011

48. UNDP. Sustainable development goals. 2020. https://www.undp.org/content/undp/en/home/sustainable-development-goals.html. Accessed 12 Jun 2020.

49. Prahdan P, Costa L, Rybski D, Lucht W, Kropp J. A systematic study of sustainable development goal (SDG) interactions. Earth's Future. 2017;5(11):1169-79. https://doi.org/10.1002/2017EF000632.

50. Anasi SN, Ukangwa CC, Fagbe A. University libraries-bridging digital gaps and accelerating the achievement of sustainable development goals through information and communication technologies. W J Sci Tech Sust Dev. 2018;15(1):13-25.

51. Lozano R. A holistic perspective on corporate sustainability drivers. Corp Soc Responsib Environ Mgmt. 2015;22(1):32-44. https:// doi.org/10.1002/csr.1325.

52. Rosati F, Faria LG. Addressing the SDGs in sustainability reports: the relationship with institutional factors. J Clean Prod. 2019;215:131226. https://doi.org/10.1016/j.jclepro.2018.12.107.

53. Bebbington J, Russell S, Thomson I. Accounting and sustainable development: Reflections and propositions. Crit Persp Account. 2017;2017(48):21-34. https://doi.org/10.1016/j.cpa.2017.06.002.

54. Griggs D, Nilsson M, Stevance A, McCollum D. A guide to SDG interactions: from science to implementation. International Council for Science: Paris; 2017.

55. Bebbington J, Unerman J. Achieving the United Nations sustainable development goals: an enabling role for accounting research. Account Audit Account J. 2017;31:2-24.

56. Fonseca A. How credible are mining corporations' sustainability reports? A critical analysis of external assurance under the requirements of the international council on mining and metals. Corp Soc Responsib Environ Manag. 2010;17(6):355-70. https://doi.org/ $10.1002 /$ csr.230.

57. KPMG. Survey of Corporate Responsibility Reporting. 2017. https://assets.kpmg/content/dam/kpmg/xx/pdf/2017/10/kpmg-surveyof-corporate-responsibility-reporting-2017.pdf. Accessed 15 Nov 2019.

58. Boiral O, Henri JF. is sustainability performance comparable? A study of GRI reports of mining organizations. Bus Soc. 2017;56(2):283317. https://doi.org/10.1177/0007650315576134.

59. Izzo FM, Ciaburri M, Tiscini R. The challenge of sustainable development goal reporting: the first evidence from italian listed companies. Sustainability. 2019;12:3494. https://doi.org/10.3390/su12083494.

60. Bennett M, Schaltegger S, Zvezdov D. Exploring corporate practices in management accounting for sustainability. Icaew: London. 2013; p. 1-48.

61. Farooq MB, De Villiers C. Understanding how managers institutionalise sustainability reporting. Account Audit Account J. 2019;32:1240-69.

62. Gardberg NA, Fombrun CJ. Corporate citizenship: creating intangible assets across institutional environments. Acad Manag Rev. 2006;31(2):329-46. https://doi.org/10.5465/AMR.2006.20208684.

63. DiMaggio J, Powell WW. The iron cage revisited: institutional isomorphism and collective rationality in organizational fields. Am Socio Rev. 1983;48(2):147-60. https://doi.org/10.2307/2095101.

64. Delmas M, Toffel M. Stakeholders and environmental management practices: an institutional framework. Bus Strat Env. 2004;13:209-22. https://doi.org/10.1002/bse.409.

65. Dare M, Schirmer J, Vanclay F. Community engagement and social license to operate. Imp Ass Proj Appr. 2014;32(3):188-97. https://doi. org/10.1080/14615517.2014.927108.

66. Deegan C. Financial accounting theory. North Ryde: McGraw Hill; 2009.

67. Susith F, Stewart L. A theoretical framework for CSR practices: integrating legitimacy theory, stakeholder theory and institutional theory. J Theo Acc. 2014;10(1):149-78.

68. Guler I, Guillen M, Macpherson J. Global competition, institutions, and the diffusion of organizational practices: the international spread of ISO 9000 quality certificates. Admin Sci Quart. 2002;47(2):207-32. https://doi.org/10.2307/3094804.

69. Seuring S, Müller M. From a literature review to a conceptual framework for sustainable supply chain management. J Clean Prod. 2008;16:1699-710. https://doi.org/10.1016/j.jclepro.2008.04.020.

70. De Villers C, Alexander D. The institutionalization of Corporate social responsibility reporting. Brit Acc Rev. 2014. https://doi.org/10.1016/j. bar.2014.03.001. 
71. Agudelo LMA, Jóhannsdóttir L, Davíðsdóttir B. Drivers that motivate energy companies to be responsible. A systematic literature review of Corporate Social Responsibility in the energy sector. J Clean Prod. 2019;247:119094. https://doi.org/10.1016/j.jclepro.2019.119094.

72. Johannsdottir $L$. Drives of proactive environmental actions of small, medium and large Nordic non-life insurance companies and insurers as a driving force of actions. J Clean Prod. 2015;108(A):685-98. https://doi.org/10.1016/j.jclepro.2015.06.055.

73. Nidumolu R, Prahalad CK, Rangaswami MR. Why sustainability is now the key driver of innovation. Harv Bus Rev. 2009; 1-10.

74. Porter ME, Kramer MR. Creating shared value: how to reinvent capitalism e and unleash a wave of innovation and growth. Harv Bus Rev. 2011;1-17.

75. Baxter P, Jack S. Qualitative case study methodology: study design and implementation for novice researchers. Qual Rep. 2008;13(4): 544-559. https://nsuworks.nova.edu/tqr/vol13/iss4/2

76. Yin RK. Case study research: design and methods. 3rd ed. Thousand, Oaks: SAGE Publications, Inc.; 2003.

77. Euromines. Members. 2020. http://www.euromines.org/who-we-are/members. Accessed 20 Jan 2020.

78. Eurometaux. Members. 2020. https://eurometaux.eu/about-eurometaux/members. Accessed 20 Jan 2020.

79. Lewis-Beck MS, Bryman A, Liao TF. The Sage encyclopedia of social science research methods. Thousand Oaks, Calif: Sage; 2004.

80. Krippendorff K. Content analysis: an introduction to its methodology. Thousand Oaks, CA: Sage; 2004.

81. Thomas DR. A general inductive approach for qualitative data analysis. School of Population Health: University of Auckland; 2003.

82. Jacobs M. The environment as stakeholder. Bus Strat Rev. 1997;8(2):25-8. https://doi.org/10.1111/1467-8616.00017.

83. Bruntland GH. Our common future: the world commission on environment and development. Oxford: Oxford University Press; 1987.

84. ICMM. Integrated mine closure-Good Practice Guide, 2nd Edition. 2019. https://www.icmm.com/website/publications/pdfs/closure/ 190107_good_practice_guide_web.pdf. Accessed 30 Aug 2020.

Publisher's Note Springer Nature remains neutral with regard to jurisdictional claims in published maps and institutional affiliations. 